\title{
Landscape Language of Modern Swedish Landscape Architects*
}

\author{
Tan Wang \\ College of Landscape Architecture \\ Sichuan Agricultural University \\ Chengdu, China
}

\author{
Jiajia Li \\ College of Landscape Architecture \\ Sichuan Agricultural University \\ Chengdu, China \\ Xiaoyu Ming \\ College of Landscape Architecture \\ Sichuan Agricultural University \\ Chengdu, China
}

\author{
Yufan Ding \\ College of Landscape Architecture \\ Sichuan Agricultural University \\ Chengdu, China \\ Xiaofang $\mathrm{Yu}^{* *}$ \\ College of Landscape Architecture \\ Sichuan Agricultural University \\ Chengdu, China \\ **Corresponding Author
}

\begin{abstract}
In the early 20th century, Swedish landscape was effected by Arts and Crafts movement, paying attention to concise, and simple style, and promoting the natural combination of landscape and buildings [1]. In 1917, the Swedish architect Aspland and the landscape architect Levilenz designed "the modern movement Parthenon"- the Stockholm forest cemetery. In 1930, the Stockholm exhibition organized by Aspland emphasized combination of nature and landscape, so that space can breathe along with the nature. Then Swedish City Park had its own design team, such as Braum, Graham etc. From 1930 1940, with functionalism introduced into Sweden, Scandinavian design in an uncomplicated, aesthetic style created a national characteristic of the landscape, where "Stockholm School" ideas has influenced the modern landscape architecture's language, such as Hermelin, S.I Anderson, Martinson, etc. [2]
\end{abstract}

Keywords-Sweden; modern landscape; architecture language of landscape

\section{INTRODUCTION}

In the early 20th century, Swedish garden was influenced by arts and crafts movement, paying attention to conciseness, simplicity and promoting the combination of landscape and architecture. In 1917, the Swedish architect Aspland and the landscape architect Levi Lenz designed the "modern movement Parthenon" — the Stockholm Forest Cemetery. The Forest Cemetery represents the dialogue between space and the environment, while expresses the most complex ideas with the least elements [3], and it is an excellent example of the combination of early architecture and landscape.

*Fund Project: Guangdong provincial science and technology project (2017B090907001)
In 1930, the Stockholm Show organized by Aspland emphasized the combination of landscape and nature, letting space and nature breathe together [4]. In the 1930s - 1940s, Scandinavian design created a nationally unique landscape in a simple and beautiful style, with Sweden and Denmark as the main ones. The "Stockholm school" advocates strengthening the "form" which is of regional landscape features in public spaces, which not only satisfies the needs of the city's environment and places, but also preserves the natural landscape [5].

In the middle of 20th century, due to the influence of the war, design activities in other countries in Northern Europe were interrupted [6]. A large number of designers and artists went into exile in Sweden. At the same time, during the boom of the Stockholm school, the urban public space began to have its own designer team.

\section{REPRESENTATIVE FIGURES}

\section{A. Aspland}

Aspland (1885-1940) is one of the most influential architects in Sweden. In 1905, he studied architecture at the Royal Institute of Technology in Stockholm. At the same time, he was the editor-in-chief of the architectural magazine. After then, he assumed as the professor of architecture there. It was an important bridge for the transition of Swedish neoclassical architecture to modernism.

Among all the masterpiece of Aspland, forest cemetery architecture design is a typical romantic classical building. Aspland's romanticism during this period was mainly 
influenced by local architecture in Northern Europe, and he continued to use local features, meanwhile, to instill classical style. The memorial church in the forest cemetery is a typical example, referring to the simple steep-roofed roof of a Swedish local building, and a classical colonnade. From 1920-1928, taking the Scandinavian cinema and the Stockholm Municipal Library as examples, Aspland's architectural style began its transition from classicism to modernism.

In 1930, Aspland's architectural style completely turned to modernism, and many functional works were designed, such as the award-winning Gordon Paul Court expansion at the Stockholm Exhibition Hall and the Woodland Crematorium.

\section{1) Words}

a) Gometry: The trapezoidal square at the entrance , and the use of square, circular, irregular paving slabs to indicate space changes in "Fig. 1", and a square pool in front of the library in "Fig. 2".

b) Artificial structures: low walls-the low walls on the left side of the ascending path are used to define the space, and the BBer Foto walls are used to separate the small cemeteries in "Fig. 3".

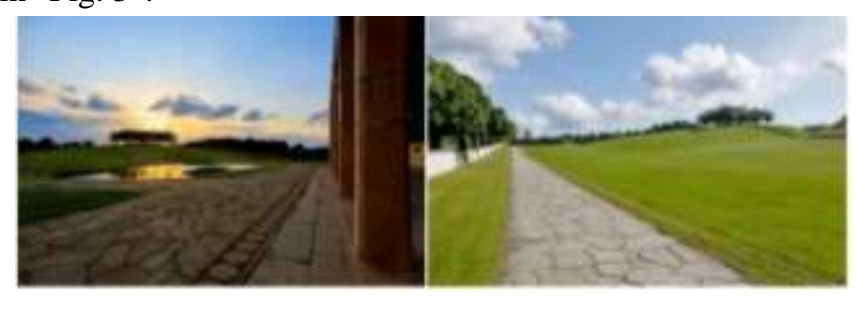

Fig. 1. The irregular pavement of Woodland Cemetery (http://wenku.baidu.com).

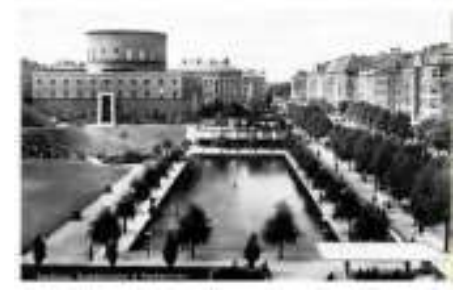

Fig. 2. Square pool in front of Stockholm Public Library (wenku.baidu.com/view).

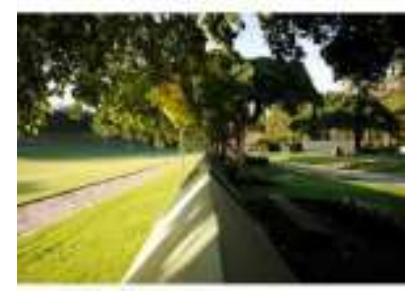

Fig. 3. The BBer Foto walls (wenku.baidu.com/view).

\section{2) Lexical rules}

a) Vocabulary references: Historical symbols and traditions cited: The Ascent Path is a reference to the ancient Pompeii cemetery road in "Fig. 4".
Agriculture and natural landscape terms cited: Typical undulating terrain in southern Swedish, woods and hills, and etc. in "Fig. 5".

Art vocabulary references/new words: Sculpture — The cross "Fig. 6" is both a basic element of the landscape and religious symbolism; a new form of landscape - the combination of modern architecture and landscape.

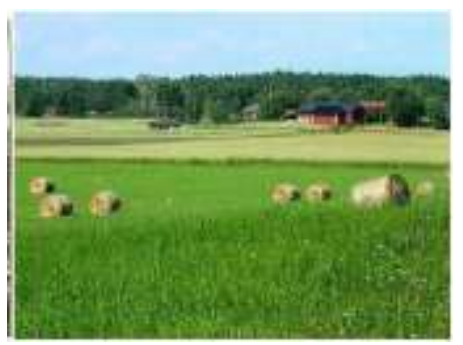

Fig. 4. The street of Pompeii Cemetery (www.quanjing.com).

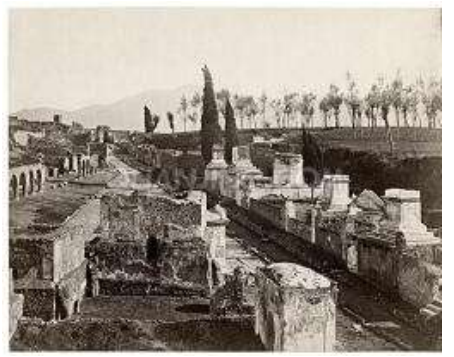

Fig. 5. Agricultural Landscape of Southern Sweden (Undulating terrain, small forests and hills) (www.uniontravelcn.com).

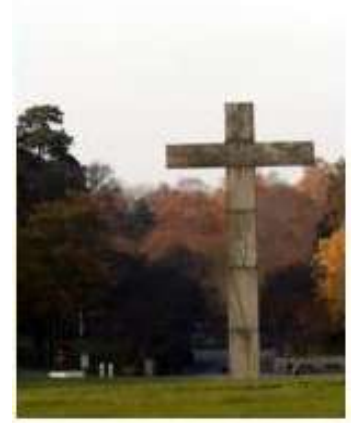

Fig. 6. the cross (blog.sina.com.cn).

b) Stylized vocabulary: natura landscape vocabulary hills and groves.

c) Integration phrase: new words and phrases to create the cross, both landscape phrase, and a symbolic sculpture. New words create a new landscape form, which is a new landscape combining architecture and landscape.

3) Syntactic rules

a) Tense: The sequence of commemorative space: overture - plot narrative — the climax cemetery's emotional and space experience. Entrance Square - large lawn in front of the square — rising path _ reborn Church — memorial Hill.

From the entrance to the woodland cemetery, the slowly rising terrain, vast sky, horizontally stretched grassland, 
verdant trees, and forests merge into an atmosphere that the sacrifice to the deceased and the sacredness of soul return to heaven, which brings comfort to the living.

b) Segment relationship and association relationship: The plaza in the entrance and the large lawn in front of the square constitute a segment relationship: broad but not empty meadows and mounds, a huge cross at the southern end of the meadow, the nearby crematorium building. By trails, travelers may board a platform on a mound surrounded by mountains. Here is an ideal "refuge", where visitors can feel the unusual peace, but it's so shocking to dialogue with the beautiful scenery. Designers leave a blank at the climax, making the visitors meditate, which is quite an ingenious and shocking blank.

\section{B. Levitenz}

Levitenz, a well-known Swedish architect, was a mechanical engineer at the Technical University of Gollborg in Chalmers initially, and later went to Germany to participate in the system of architecture. He once founded his own company and participated in the design of the Stockholm Forest Cemetery in this period, winning the competition in Stockholm South Cemetery. The construction of the project was completed by Aspland alone. Levitenz was appointed as the main architect of the Stockholm International Exhibition in 1930, and he left there ten years later. Due to the design of St. Mark's Church in Björkhagen, Stockholm, he reappeared in the public. His victory in the design of the church brought him back to the architectural arts, and his proper use of building materials attracted the St. Mark's Church international attention.

In the last decade of his life, he designed two churches: San Marco (1956) and St. Peter's Cathedral (1963), located in Björkhagen and Klippan in Stockholm. Levitenz's architectural features are beautifully displayed in the details of the building, the choice of materials, the quality of the light and the clarity of the space.

\section{1) Words}

- Geometry: square pool;

- Sculpture: Water features in the pool (Fig. 7), Bell Tower (Malmo Cemetery);

- Bricks: Gray bricks with the rough touch and texture of St. Mark's Church (1956) and St. Peter's Church (1963);

- Trunk "wall": A row of tree "walls" planted on the main road of the Malmö cemetery, "walls" of poplar trees listed in the entrance to the forest cemetery.

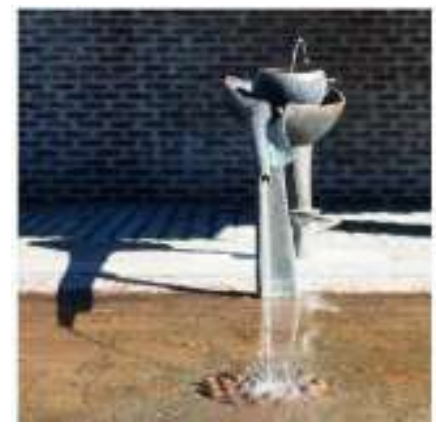

Fig. 7. The water features device of St.Mark church (howardchanxx.net).

\section{2) Lexical rules}

a) Vocabulary references: Citation of artistic vocabulary: Sculpture —— water features, bell tower;

References to architectural vocabulary: Bricks — grey brick paving of St. Peter's Church in front of the entrance to St. Mark's Church;

References to other designer vocabulary: References to Aalto architectural vocabulary - bricks with irregular tiles.

b) Stylized vocabulary: Sculpture, bricks.

c) Integration phrase: The new meaning of the word — a wall of rough and seamed bricks ${ }^{1}$ in "Fig. 8".
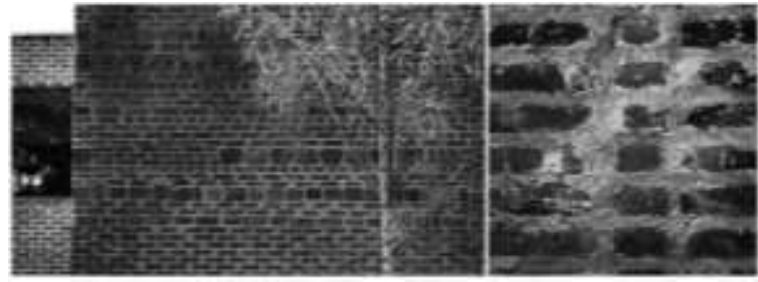

Fig. 8. The brick walls ( howardchanxx. net).

\section{3) Syntactic rules}

- Order: Grid — The high hedge trimmed on the main road is the grid of the Cemetery of Malmö to divide the room.

- Comparison: The contrast between Flat cemetery ground level and vertical tall clock tower; the contrast between groves on both sides of the road and the buildings in "Fig. 9"; the contrast between rough brick wall of the church and the pure glass surface in "Fig. 10". The role of the cross in the forest cemetery designed by Levitenz is the same as that of the clock tower in the Malmö cemetery. It is an extension of the horizontal element by means of vertical elements, which has become the most characteristic landscape language in Levitenz.

- Segment relationship and association relationship: The two buildings of St. Mark's Cathedral and the courtyard of the square pool in the middle constitute the segmental relationship of the entire church, and the

Refers to the "bag-type leveling method" used by Levi Lenz in the landscape, that is, the use of rough and coarse sacks to smooth wide seams. 
middle square pond courtyard is transitional space as space pauses and connections.

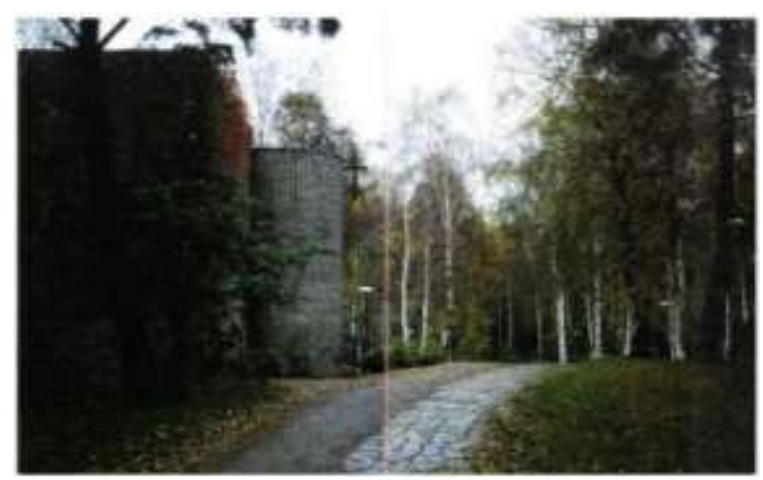

Fig. 9. The contrasts of road on both sides of the woods and architecture ( howardchanxx. net).

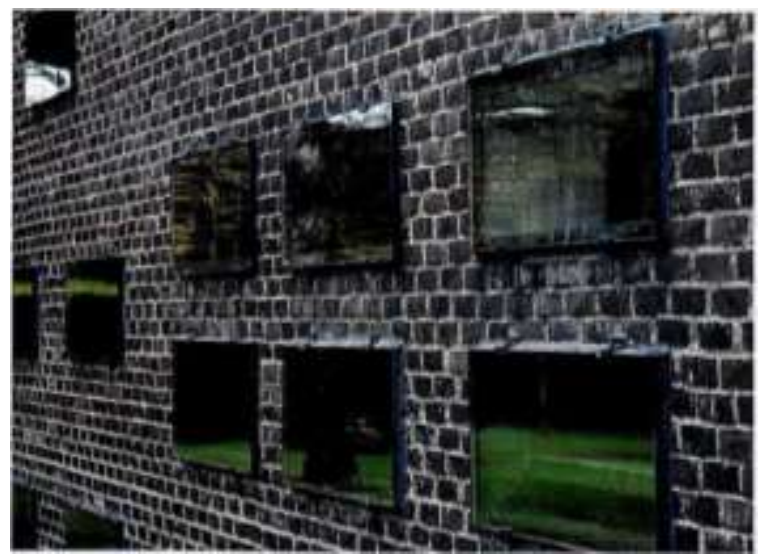

Fig. 10. Comparation between rough brick walls and a pure glass surface ( howardchanxx. net).

\section{Hermelin}

Hermelin is an important modern garden designer in Sweden who devoted his life to expanding the professional scope of landscape design and strengthening the domestic and foreign exchanges of Swedish gardens. He advocated the garden's outward natural traditions and made good use of native plants. The idea of democratic equality is reflected in the garden's or parks functional role in human health in Hermelin's garden. His outward-looking natural attitude and democratic equality thought greatly influenced Swedish landscape architects and designers in the 50s and 70s, such as Braum, Graeme and Martinson, etc.

1) Words

- Curve: Following the natural language, Hermelin plans the road network and divides the space in a curve.

\section{- Rest kiosk}

2) Lexical rules

- Citation of words: Natural landscape vocabulary of reference — Open space, small hills, wide grasslands and forest margins;
- Termization of words: The stylization of agricultural landscape and natural landscape vocabulary _- Open space, small hills, wide grasslands and forest margins;

- Integration of phrases: Creation of new phrases Natural form of garden.

\section{3) Syntactic rules}

- Tense: The reproduction of natural landscape elements _ forest glades, hills, wide grasslands and margins of marginal borders;

- Architectural approach: Functionality is reflected in the play pool and lounge pavilion.

- Segment relationship and association relationship: Hermelin connects the Swedish agricultural landscape elements groves, forest vacancies, hills, meadows and artificial elements (rest kiosk) to form a segment relationship. In the local plant space where the curves are enclosed, people's sensory experience and physical and mental health are emphasized.

\section{Martinson}

Martinson studied gardening and architecture in Stockholm, working (then worked) in Valentin, Germany, and Hermann Grove in Stockholm. In 1963, a residential garden was designed at the Hamburg International Horticultural Exposition, which brought Scandinavian garden design out of the country for the first time. His designs are deeply influenced by Brandt and Sorensen. They often use simple geometric vocabulary but rarely use Swedish natural landscape vocabulary such as forest margins or meadows. What inherited from the two masters is using pruned hedgerows to separate the space, emphasizing the functionality and architecture of the landscape.

1) Words

- Geometry — rectangles, squares, triangles

- The square flower ponds, cubed hedge trimmings are fully revealed in the fig orchard and snowberry forest designs, and are also reflected on the Nykoping Town Hall courtyard and the Rocksta cemetery.

2) Lexical rules

- Quoting of words: square;

- Typification of words: square;

- Combination of phrases: creation of new phrases square combinations.

3) Syntactic rules

- Grid: Grid — in the Norrviken Garden Show's plan for the residential residence competition, the courtyard grid corresponds to the structure of the building.

- Building method: Spaces are divided by hedgerows - Martenson uses fences and cubic hedges to enclose and separate spaces.

- Segment relationship and association relationship: In the Sonla Kungshamra student residence, both the fig orchard and the snow orchard are regard cube as the 
theme, forming a decomposed relationship between the cube and the entire space.

\section{CONCLUSION}

With the development of Swedish modern gardens, Aspland has used a symbol of national landscape in the forest cemetery. The Stockholm has introduced nature into the city, and Hermelin has explored the characteristics of Swedish landscape. They always aim at the pursuit of "nature". The exquisite natural scenery and prosperous farming scene has formed the attitude of paying attention to nature in modern Swedish garden.

\section{REFERENCES}

[1] Yan Zhen, Recognition of "the Nordic model”, Xinhua Digest,2009, pp. 22-25.

[2] Yuhua Liu, Western modern gardens after the 1990s, Nanjing Forestry University, 2006.

[3] Xin Wang, Overview of Nordic landscape design and development, Beij ing Forestry University, 2006.

[4] Xiangrong Wang, The modern landscape of the Nordic countries, China Architecture \& Building Press, 2007.

[5] Tingting Shu, Introduction to modern Swiss landscape development, Bei jing Forestry University, 2009.

[6] Xiaoying Meng, Research on the languuage of Nordic modernism landsc ape design: 1920-1970, Beijing Forestry University, 2006.

[7] LA Forum.A convergence of ISMS. Landscape Architecture, 1990, pp. 5 6-61 